\title{
Great Expectations? A Comparative Analysis of Bachelor and Graduate Level Engineering Students' Expectations of University and Experiences of Transition
}

\author{
Dr. Jane Andrews, Aston University
}

Dr Jane Andrews is a Senior Lecturer in Engineering Education at the School of Engineering \& Applied Science, Aston University, UK. The only Sociologist in the UK to hold a lectureship in Engineering, Jane's research interests include all aspects of engineering education with a particular focus on elementary level engineering education and gender issues within engineering.

Prof. Robin Clark, Aston University 


\section{Great Expectations? A Comparative Analysis of Bachelor's and Graduate Students Expectations of University to Combat the Trauma of Transition}

\section{Abstract}

This paper critiques how engineering students experience two key academic transition points in UK Higher Education, foundation (pre-freshman) and graduate level study. Set within an era whereby the dominant ideology is that of marketization, the paper considers whether student expectations of the academic side university are similar at foundation and graduate level. Descriptive statistics are used to compare and contrast the student perspective and a number of key differences between the expectations of both cohorts critiqued. The paper concludes by emphasing the need for Synergetic Configuration across the curriculum

\section{Key words: Synergy: Variety: Synergetic Configuration: Foundation students: Graduate Students}

\section{Introduction \& Background}

Based upon the pedagogically focused aspects of the RVS model of Engineering Education ${ }^{[1]}$ and following an Action Research approach ${ }^{[2]}$ the Great Expectations Project set out to identify and find solutions to the issues around the 'academic transition' into university for two very different cohorts of students; those who enter university without the required prerequisite qualifications and are therefore required to enrol upon a pre-undergraduate level 'conversion' programme in general engineering; and students who, having graduated with a Bachelor's in an engineering discipline, enrol upon a one-year fulltime MSc in Engineering Management. Set within a national context whereby responsibility for financing Higher Education in the UK has shifted from being the responsibility of the state to individual students ${ }^{[3]}$, undergraduate fees are currently set at between $\$ 12000$ and $\$ 18000$ per year (with the two different amounts representing UK / EU and overseas students respectively). Graduate fees across the UK are set institutionally and generally range from between $\$ 8700$ to $\$ 18000$ for a one year Master's level programme (MBA and MPhil fees can be much higher). This systems is operationalised through a complicated mixture of 'student' loans and individual debt.

Somewhat predictably, the marketization of Higher Education (H.E.) has been accompanied by a rise in student expectations; with unprecedented pressures placed on academic and support staff to facilitate and enhance student success ${ }^{[4,5,6]}$. Conversely, the concepts of "academic freedom" and the idea that students' should be responsible for themselves both seem to be rapidly disappearing; only to be replaced by corporate style managerialist organizational strategies and 'customer savvy students'. Moreover, as pressures on university staff to provide highly individualised educational experiences have risen, so student numbers have increased. Although more student having access to H.E. is one of the successes of marketization, some evidence exists to suggest that universities have lowered their standards in terms of prerequisite qualifications ${ }^{[7,8]}$. This has resulted in a situation whereby admissions benchmarks in terms of High School level qualifications have changed markedly, with students from a wider range of socio-economic and educational backgrounds now entering university. 
Within this context, previous studies by the paper authors into how first year students experience university found that a sense of belonging is crucial to student success. Additionally, the transition into university was identified as being particularly difficult for students from 'non-traditional' backgrounds including those from Black and Minority Ethnic (BME groups), and those without the 'traditional' academic qualification ${ }^{[9,10]}$. Both of these variables are strongly present in the two cohorts sampled as part of this project.

Over the past two decades much attention has been paid to gaining students' perceptions of their university experience, particularly in terms of 'satisfaction' ${ }^{[11,12]}$. Yet despite this emphasis very few studies have sought examine what new students actually expect from university. As a consequence of this much of the work undertaken in the UK to help students transition into university is done on a 'trial and error' basis, with colleagues working hard to provide a high quality experience, whilst not fully understanding the students' perspective. In order to address this issue the Great Expectations Project set out to identify and analyse what engineering students' expect from university, the findings from investigation are presented in this paper and a set of recommendations given.

\section{Methodology}

\subsection{Study Approach}

The primary aim of the Great Expectations Project is to better align student expectations with their experiences, particularly in the often difficult 'transition period' of the first term. Starting with the research question "How can student transition into university be improved at both foundation and graduate level?" and building on previous literature ${ }^{[13,14]}$, an Action Research philosophical approach was adopted to identify and critique students' expectations of university.

Using an electronic survey tool the two cohorts of students were surveyed independently and the findings cross-tabulated. The survey questions were based upon Tinto's $(1987,2010)$ work and divided into two areas: drivers and barriers to university: preferences and expectations of study ${ }^{[15,16]}$. The questions were built around "Agreement Likert Scales" and presented in a matrix fashion.

The findings of the study are presented in tabular format utilising descriptive statistics based upon percentages. The reason for this is reflective of the research philosophy that underpins the project; it is important that the findings and outputs are fully accessible to a range of colleagues including non-academic support staff.

\subsection{Sampling}

Two different cohorts were sampled, the first comprising 150 students on a 'General Engineering Foundation Programme' at pre-undergraduate level, the second, 65 graduate students studying 'Engineering Management'. Figures 1 and 2 provide an overview of the sample demographics. As discussed above, from Figure 2 onwards all statistics are given in percentages only. 
Figure 1: Sample: Programme Breakdown

\begin{tabular}{|l|l|l|l|}
\hline Level & $\boldsymbol{N}$ & $\mathbf{\%}$ & \\
\hline Freshman (FY) & 150 & $70 \%$ & \\
\hline Graduate (PG) & 65 & $30 \%$ & \\
\hline TOTAL & $\mathbf{2 1 3}$ & & \\
\hline
\end{tabular}

Table 2: Sample: Demographic

\section{Characteristics}

\begin{tabular}{|l|l|l|l|}
\hline Character & $\begin{array}{l}\text { ALL: } \\
\mathbf{\%}\end{array}$ & $\begin{array}{l}\text { PG: } \\
\mathbf{\%}\end{array}$ & $\begin{array}{l}\text { FY: } \\
\mathbf{\%}\end{array}$ \\
\hline Male & 82 & 74 & 83 \\
\hline Female & 18 & 26 & 17 \\
\hline Overseas & 15 & 67 & 5 \\
\hline Disability & 3 & 0 & 4 \\
\hline Prior work experience & 53 & 53 & 48 \\
\hline Under 21 years & 78 & 0 & 93 \\
\hline Over 22 years & 22 & 100 & 7 \\
\hline
\end{tabular}

In examining the sample demographics a number of differences are evident, the most notable of which reflects the fact that $67 \%$ of the graduate students sampled were from outside of the UK / EU and thus classified as 'overseas students'. This figure compares with $15 \%$ of Foundation Year students. The percentage of overseas students on both programmes is higher than the national picture whereby $46 \%$ of graduate students are from outside of the UK / EU compared to only $3 \%$ of undergraduates ${ }^{[17]}$. The differentiation between the national average and the percentage of non-UK / EU students at Gosta University is possibly reflective of the geographic location of the University, which is sited in one of the UK's most ethnically diverse cities. Additionally, it should be noted that Gosta University is a "minority-majority" university, with over $60 \%$ of its students originating from Black \& Minority Ethnic (BME) backgrounds.

\section{Findings}

This section provides an overview of the percentage of students within each cohort who either "Strongly Agreed" or "Agreed" with each question statement. Three tables are presented, with the data thematically. A brief discussion of the main points of note relating to each table is given

\subsection{Drivers \& Barriers to Studying Engineering}

In seeking to identify what students expect from university, the survey began with a focus on why students select to study engineering. Based upon the literature and taking account of the findings of studies previously conducted by the paper authors, three sub-themes were used to frame the questions: social drivers: individual and personal drivers: career \& employment drivers. Figure 3 provides an overview of the percentage of students who either agreed or strongly agreed with the statements outlined. 
Figure 3: Factors influencing students' decisions to study engineering (Drivers)

\begin{tabular}{|l|l|l|l|}
\hline $\begin{array}{l}\text { My reasons for choosing to study engineering at } \\
\text { university are... }\end{array}$ & $\begin{array}{l}\text { ALL } \\
\mathbf{\%}\end{array}$ & $\begin{array}{l}\text { PG } \\
\mathbf{\%}\end{array}$ & $\begin{array}{l}\text { FY } \\
\text { \% }\end{array}$ \\
\hline Social Drivers & & & \\
\hline I want to make a difference to global society & 86 & 91 & 83 \\
\hline $\begin{array}{l}\text { A degree in engineering will give me the skills and } \\
\text { knowledge to positively influence those around me }\end{array}$ & 79 & 66 & 85 \\
\hline $\begin{array}{l}\text { Being an engineer will put me in a good position to } \\
\text { act as a role model to friends, colleagues and } \\
\text { younger people }\end{array}$ & 65 & 28 & 81 \\
\hline $\begin{array}{l}\text { Individual \& Personal Drivers } \\
\text { A degree in engineering will give me more choices } \\
\text { in life }\end{array}$ & 92 & 76 & 95 \\
\hline $\begin{array}{l}\text { Being a university student studying engineering } \\
\text { gives me a level of respect from my friends }\end{array}$ & 52 & 31 & 57 \\
\hline Career \& Employment Drivers & & 92 & 97 \\
\hline $\begin{array}{l}\text { Completion of the course will facilitate the } \\
\text { opportunity for me to work on future exciting and } \\
\text { innovative projects }\end{array}$ & 95 & 92 & \\
\hline $\begin{array}{l}\text { A degree in engineering will provide evidence that I } \\
\text { am a capable engineer }\end{array}$ & 88 & 74 & 92 \\
\hline
\end{tabular}

In comparing the answers given by the two different cohorts, a number of interesting features emerge. Within the sub-theme of 'social drivers' the most notable difference is the proposition that "Being an engineer will put me in a good position to act as a role model to friends, colleagues and younger people". A lack of good role models in engineering has been identified in a number of previous studies as being important to recruiting future engineers $[18,19,20]$, that less than a third of the graduate students agreed with this statement is somewhat perturbing, as all of this sample were already engineers.

Likewise, variation between the two cohorts with regards to the question statements within the sub-theme 'individual and personal drivers' is somewhat surprising. It appears that foundation students view engineering in a more positive light than do graduate students. The final point of note relates to students' perceptions of being a 'capable engineer' and raises questions about graduate students' prior qualifications and educational experiences. That around a quarter of graduate students did not agree with the statement that "A degree in engineering will provide evidence that I am a capable engineer" raises some important questions about the quality of their a priori education and experiences. Over $90 \%$ of graduate students enter Gosta with a Bachelor's Degree from a different university, with the majority of these being acquired overseas. The responses to this question infer that a substantial minority did not believe their first degree provided evidence that they were capable engineers reinforces the need for a high quality engineering curriculum at graduate and undergraduate levels. 
Having examined the "drivers" impacting engineering students' expectations each survey then focused on student concerns. Two different sub-themes were identified: individual study related anxieties: programme related concerns. Figure 4 provides an overview of the positive responses (in terms of agreement) to the question statements.

\section{Figure 4: Barriers to Study}

\begin{tabular}{|l|l|l|l|}
\hline & $\begin{array}{l}\text { ALL } \\
\%\end{array}$ & $\begin{array}{l}\text { PG } \\
\%\end{array}$ & $\begin{array}{l}\text { FY } \\
\%\end{array}$ \\
\hline Individual Study Anxieties & & & \\
\hline $\begin{array}{l}\text { I am concerned that I will find the course } \\
\text { academically difficult }\end{array}$ & 62 & 74 & 59 \\
\hline $\begin{array}{l}\text { I am worried about managing my time whilst } \\
\text { studying }\end{array}$ & 80 & 82 & 80 \\
\hline $\begin{array}{l}\text { I am worried that I don't have the level of written } \\
\text { skills I will need to be successful in my studies }\end{array}$ & 31 & 46 & 28 \\
\hline Programme Related Concerns & & & \\
\hline $\begin{array}{l}\text { I am concerned about the technical content of the } \\
\text { programme }\end{array}$ & 45 & 54 & 43 \\
\hline $\begin{array}{l}\text { It is difficult for me to see how the whole programme } \\
\text { fits together }\end{array}$ & 39 & 26 & 44 \\
\hline $\begin{array}{l}\text { I am concerned that I won't feel comfortable with } \\
\text { some of the teaching methods used at university }\end{array}$ & 51 & 55 & 50 \\
\hline
\end{tabular}

A comparison of the data from both cohorts suggests that with regards to student expectations of whether university level study will be technically or academically difficult, graduate level students tend to be more concerned about how they will cope than the younger and less experienced foundation students. This may well be indicative of naivety on behalf of those at foundation level. Alternatively, the fact that the majority of graduate students speak English as a second language may be a determining factor influencing such concerns.

\subsection{Learning Preferences}

Having examined drivers and barriers to learning the next section of the survey focused upon learning preferences. The decision was taken to theme the questions 'positively', with the intention of engendering a degree of confidence within each sample.

Two main sub-themes were identified: study support: learning in the classroom \& lab. Figure 5 provides an overview of the percentage of students in each group who either agreed or strongly agreed with each question statement. 
Figure 5: Students' Learning Preferences and Expectations

\begin{tabular}{|l|l|l|l|}
\hline Student Preferences \& Expectations & $\begin{array}{l}\text { ALL } \\
\%\end{array}$ & $\begin{array}{l}\text { PG } \\
\%\end{array}$ & $\begin{array}{l}\text { FY } \\
\%\end{array}$ \\
\hline Student Support & & & \\
\hline $\begin{array}{l}\text { I prefer to be given pre-reading so that I } \\
\text { can prepare for lectures in advance }\end{array}$ & 72 & 61 & 85 \\
\hline $\begin{array}{l}\text { I expect there to be a high level of } \\
\text { academic support available should I } \\
\text { experience difficulties }\end{array}$ & 93 & 81 & 95 \\
\hline $\begin{array}{l}\text { It is important that I have access to } \\
\text { recordings of lectures and tutorials when I } \\
\text { am studying }\end{array}$ & 91 & 87 & 92 \\
\hline Learning Preferences & & & \\
\hline $\begin{array}{l}\text { I find working in groups beneficial to } \\
\text { learning }\end{array}$ & 71 & 84 & 68 \\
\hline $\begin{array}{l}\text { I prefer traditional lectures where I sit and } \\
\text { take notes and the lecturer talks }\end{array}$ & 48 & 44 & 49 \\
\hline $\begin{array}{l}\text { I prefer to be in a learning environment } \\
\text { where a range of different teaching } \\
\text { methods are used }\end{array}$ & 70 & 60 & 74 \\
\hline $\begin{array}{l}\text { I find role-play a good way of acquiring } \\
\text { and practising 'people management' skills }\end{array}$ & 52 & 77 & 48 \\
\hline $\begin{array}{l}\text { I prefer active learning approaches such } \\
\text { as model making and group work }\end{array}$ & 72 & 77 & 71 \\
\hline $\begin{array}{l}\text { I prefer problem based learning } \\
\text { approaches }\end{array}$ & 83 & 89 & 83 \\
\hline
\end{tabular}

In examining the above table the most striking difference between the expectations of foundation and graduate students relates to anticipated levels of support. Foundation level students envisage that they will receive much higher levels of academic support with 95\% expecting academic help should they find their programme difficult. One of the factors impacting students at this level is possibly linked to how young people are taught at High School level. A culture of "bottle-feeding" pupils throughout their school-life reflects a system whereby teachers are put under tremendous pressure to prove their own and their school's academic credentials within a highly competitive public system of league tables and rankings ${ }^{[21,22]}$. Such a culture has created a generation of highly dependent young people, many of whom, upon arriving at university, need to be taught how to learn ${ }^{[23]}$

Variance across the two cohorts' learning preferences reflects different epistemological backgrounds, with graduate students indicating a preference for group work, whilst foundation students lean towards a blended learning approach. Perhaps not surprisingly, given the fact that the sample comprised solely of engineering students, both cohorts indicate a liking for problem based learning approaches 


\section{Driving Variety \& Combatting Barriers: A Synergetic School Level Strategy}

This importance of the Great Expectations Project reflects the need for universities to better manage transition into university across all levels of study, but particularly for those students embarking on a shorter course of study. The data from the project has been used to inform a series of interventions, each of which is framed by one of two key concepts identified within the RVS approach to Engineering Education ${ }^{[1]}$. These two concepts are Variety and Synergy, with the interventions purposefully constructed so as to promote the 'academic transition' into university for the two different cohorts of students. Concurrently, students' social and wellbeing related needs and expectations, which are captured within the Relationships strand of the RVS approach, are being considered within a parallel project, Engaging Engineering Students This second project is also being managed by the paper authors (and the findings presented in an alternative paper).

The responses to the question statements pertaining to the drivers and barriers displayed in Figures 3 and 4 provide some insight into student concerns about, and expectations of, university. Whereas the data displayed in Figure 5 gives some indication of student expectations in terms of the level of support each distinctive cohort expects to receive. Figure 5 also depicts students' preferences in terms of learning and teaching approaches. The first variable in Figure 3 (social conscience), translated directly into an area for 'transition development' and considerable thought was given as to how the School of Engineering could maximize students' philanthropic inclinations.

Supported by the School of Engineering, Gosta University engineering students actively participate in a number of socio-engineering focused societies and activities including Engineers without Borders and Women's Engineering Society. To better align these activities with individual student's reasons for studying engineering, and in order to promote a more focused transition into university, the foundation students were given information on such activities and student engineering societies during freshers week. Plans are in hand to embed 'engineering philanthropy' into next year's Professional Skills module wherein the benefits of volunteering within the engineering discipline, both in terms of making a difference to society but also with regards to promoting individual employability and self-directed learning will be emphasized.

Additionally, working with colleagues, a number of mentoring opportunities aimed at foundation students were offered and supported by the School. One such opportunity involved students going into inner city schools to offer mentoring in mathematics. Whilst other students were recruited for a foundation level Peer Assisted Learning project, providing maths mentoring for their peer group. At graduate level, finding time outside of the curriculum to enable the students' to participate in such activities proved to be more challenging. However, the two paper authors co-teach a module on Engineering Corporate Social Responsibility. As a result of the Great Expectations Project, the learning objectives associated with this module have been amended so as to better emphasize the need for individual and organizational social and ethical awareness. The assessment for this module has been altered to encourage graduate students to use their engineering and analytical skills to work with non-profit heritage sites within the UK.

In considering the individual and employment related drivers, one of the paper authors has developed and introduced a new graduate learning strategy which has been disseminated 
across the School of Engineering. Within this strategy, priority is given to employability and the role played by industry in terms of curriculum development and programme governance. Additionally, Gosta University has a robust and forward-thinking Careers Service; encouraging Programme Directors to interact with and use the Careers Service has been a key part of the work undertaken by the paper authors. Right from the beginning of their programme, graduate students are offered the opportunity to attend workshops on all aspects of employability and employment, including CV writing, applying for jobs, interview skills and communicating with employers.

For foundation students, the prospect of a future career in engineering represents a key aspirational driver impacting expectations of what a university education will deliver. Most foundation students expect that their degree will directly lead to employment as an engineer four to five years down the line. Whilst the need to provide foundation students with key study related skills in maths and physics is a priority during the initial phase of the foundation programme; students' career related expectations have also been considering in a recent redesign of the curriculum. As a result of the Great Expectations Project, the 'Professional Skills' element of the foundation level curriculum has been changed markedly, with a shift towards active learning approaches based upon 'real-life' engineering case-studies and professional ethics.

In making changes to the curriculum to enhance transition into university across the first term for both foundation and graduate level students, the project leaders took into account of the barriers identified in the project. At both levels this involved the provision of additional study support from week 1. For foundation students such support centered upon maths and physics, whilst at graduate level improved access to English language training and academic writing support were identified as being key to crucial to promoting a good transition into university. Under the leadership of one of the paper authors, changes made across the School with regards to the consistency of the learning experience and information given to students about how each programme fits together as soon as they enter the university. This simple action in itself has promoted a better transition by making students feel more informed about their studies.

In positively seeking to redress student worries and concerns highlighted in the Great Expectations Project Focus Groups are regularly held to elicit students' views and to make sure appropriate actions are taken. At Foundation level, informal termly cohort meetings have been introduced whereby both paper authors make time to meet and talk with students in a non-academic and supported environment. As a result of such meetings, and taking into account the findings about students' learning preferences, colleagues have been encouraged to introduce blended learning approaches across the foundation year curriculum. Regular School Learning \& Teaching Forums and Workshops provide teaching staff with the opportunity to share best practice and access training from national leaders in engineering education.

\section{Discussion}

Frequently associated with new 'learning technologies' innovation within the H.E. curriculum is generally viewed as contributing to a positive student experience. Building on previous studies relating to learning approaches ${ }^{[24,25,26,27]}$ the Great Expectations Project 
aimed to provide the basis by which a balance between student expectations and the realities of university could be found and a 'smooth' transition into university promoted.

Foundation and graduate level programmes share a common format in that they are offered over a single academic year on a full time basis. This means that students have to quickly adapt to a new environment as formative assessment starts early on in the academic year. By introducing empirically grounded enhancements to student transition the Great Expectations Project has promoted the concept of variety in learning and teaching at both foundation and graduate levels. A key component of the RVS approach ${ }^{[1]}$, Variety is key to student success and as such needs to be embedded right from the onset of all engineering programmes (but particularly shorter courses such as the two discussed in this paper). Variety does not only center upon learning and teaching, it also encapsulates assessment and study support. If utilised fully, embedding the concept of Variety into the student experience can enable the diverse expectations of the current generation of student to be met.

In introducing a number of student-focused interventions and curriculum changes, Gosta University School of Engineering aims to equip its students with the high level of skills and capabilities necessary to successfully fulfil four distinctive roles within future society: proactive problem identification and solving: science and research: technical design based upon 'blue-skies' thinking: community leadership ${ }^{[28]}$. The need to align these four roles across the curriculum, from transition through to graduation, falls within the remit of the second concept of the RVS approach used to inform the Great Expectations Project, that of Synergy. Synergy takes the notion of Constructively Alignment ${ }^{[29]}$ one stage further, encapsulating societal, educational and industrial demands and expectations ${ }^{[1]}$. The data displayed in the Figures 3, 4 and 5, viewed either holistically or individually, reinforces the value of promoting a synergetic approach to the student experience. Students' expectations are subject to a range of influences, all of which are present during the transition period. It is therefore vital that in managing engineering students expectations colleagues are aware of the need to view the student experience holistically. If considered concurrently, academic, social and individual matters can result in a high quality synergetically configured transition into university and subsequent learning experience

It is the need for Synergetic Configuration ${ }^{[30]}$ during the transition period that forms the primary outcome of this project. Defined as "the requirement that university level Engineering Education should equip students with the technical capabilities required by industry, whilst providing them with a sound theoretical knowledge base, within a supportive curriculum in which 'softer skills' are embedded alongside technical competencies and independent learning is the norm", the evidence presented in this paper shows that it is equally important for student experiences to be aligned with their expectations at both ends of the traditional HE learning journey.

In conclusion, both foundation and graduate students are prone to experience a somewhat difficult transition into university. By analysing the drivers and barriers to university within the context of transition, and by considering students learning preferences, this paper has shown that there is a clear need to take steps to build a positive transition into university irrespective of level of study. "Transition" does not simply refer to freshers week; for many students familiarisation with the university environment and learning culture can take considerable time. The project has shown that by taking steps to engender a sense of community and belonging much can be done to promote a good transition into university. 


\section{References}

1. PAPER AUTHORS - ANONYMISED

2. Norton, L.S., (2009). Action research in teaching and learning: A practical guide to conducting pedagogical research in universities. London. Routledge.

3. Gibbs, P. (2001) "Higher education as a market: a problem or solution?." Studies in Higher Education 26. 1. pp. 85-94.

4. Tricker, T., (2005) Student Expectations- How do we measure up. University of Sheffield. Available from: http://interdisciplinary.net/ati/education/ioe/ioe2/tricker\%20paper.pdf Accessed 7/2/17

5. Arambewela, R. (2010). Student experience in the globalized higher education market: Challenges and research imperatives. Globalization and internationalization in higher education: Theoretical, strategic and management perspectives, 155-173.

6. Gurney-Read, J. (2014) Meeting students high expectations. The Telegraph. 3/6/14. http://www.telegraph.co.uk/education/educationopinion/10872594/Meeting-studentshigh-expectations.html Accessed 7/2/17

7. Paton, G. \& Carter, C. (2014). Universities lowering entry grades to fill places this year. The Telegraph. 14/8/14.

http://www.telegraph.co.uk/education/educationnews/11035385/Universitieslowering-entry-grades-to-fill-places-this-year.html Accessed 10/2/17.

8. Coughlan, S. (2016). University lowers entrance grades for disadvantage. $B B C$. 15/12/17. http://www.bbc.co.uk/news/education-38301844 Accessed 10/2/17.

9. PAPER AUTHORS - ANONYMISED

10. PAPER AUTHORS - ANONYMISED

11. PTES (2016) Postgraduate Taught Experience Survey https://www.heacademy.ac.uk/institutions/surveys/postgraduate-taught-experiencesurvey Accessed 7/2/17

12. NSS (2016) National Student Survey http://www.hefce.ac.uk/lt/nss/results/2016/ Accessed 7/2/17

13. Hernandez-Martinez, P., (2016). "Lost in transition": Alienation and drop out during the transition to mathematically-demanding subjects at university. International Journal of Educational Research. https://www.researchgate.net/profile/Paul_Hernandez-

Martinez/publication/297225891_Lost_in_transition_Alienation_and_drop_out_durin g the transition to mathematicallydemanding_subjects_at_university/links/56ddbcba08ae628f2d24ae30.pdf Accessed $7 / 2 / 17$ 
14. Pampaka, M., Williams, J. and Hutcheson, G., (2012). Measuring students' transition into university and its association with learning outcomes. British Educational Research Journal, 38. 6. pp. 1041-1071.

15. Tinto, V., (1987). Leaving college: Rethinking the causes and cures of student attrition. University of Chicago Press, 5801 S. Ellis Avenue, Chicago, IL 60637.

16. Tinto, V., (2010). From theory to action: Exploring the institutional conditions for student retention. In Smart, J.C. (Ed) Higher Education: Handbook of Theory and Research. Volume 25. pp. 51-89. Springer. Netherlands.

17. HESA (2016) HE student enrolments at HE providers in the UK by level of study, mode of study and domicile 2015 / 16. Higher Education Statistics Authority. http://institutions.ukcisa.org.uk//Info-for-universities-colleges--schools/Policyresearch--statistics/Research--statistics/International-students-in-UK-HE/ Accessed $8 / 2 / 17$.

18. Pereira, D., 2014. Improving female participation in professional engineering geology to bring new perspectives to ethics in the geosciences. International journal of environmental research and public health, 11(9), pp.9429-9445.

19. Hartman, H. and Hartman, M., 2008. How undergraduate engineering students perceive women's (and men's) problems in science, math and engineering. Sex roles, 58(3-4), pp.251-265.

20. Phillips, J.A. and Head, N.W., 2000. Role Models in Engineering and Technology. age, 4, ASEE. PEER. https://peer.asee.org/role-models-in-engineering-andtechnology Accessed 8/2/17

21. Paton, G. (2012) Spoon fed students given tuition in basic skills at university. The Telegraph. $3 / 4 / 12$.

http://www.telegraph.co.uk/education/educationnews/9180982/Spoon-fed-studentsgiven-tuition-in-basic-skills-at-university.html Accessed 9/2/17

22. Ramsey C. (2017) If we are serious about raising standards in universities improving the transition from the sixth form must be a priority. The Telegraph. 10/1/17. http://www.telegraph.co.uk/education/2017/01/10/serious-raising-standardsuniversities-improving-transition/ Accessed 9/2/17

23. Blessinger, P. and Carfora, J.M., 2015. Innovative Approaches in Teaching and Learning: An Introduction to Inquiry-Based Learning for STEM Programs. In Inquiry-Based Learning for Science, Technology, Engineering, and Math (Stem) Programs: A Conceptual and Practical Resource for Educators (pp. 3-19). Emerald Group Publishing Limited.

24. Entwistle, N. (1991). "Approaches to Learning \& Perceptions of the Learning Environment". Higher Education. 22. 2. pp 201-204.

25. Entwistle, N. \& Ramsden, P. (1982). Understanding Student Learning. New York, Croom Helm

26. Biggs, J. (1996). "Enhancing teaching through constructive alignment." Higher education 32.3. pp. 347-364.

27. Cuthbert, P.F. (2005). "The Student Learning Process: Learning Styles or Learning Approaches?". Teaching in Higher Education. 10. 2. pp 235-249.

28. Figueriedo, A. (2008) 'Towards an Epistemology of Engineering'. Proceedings of Workshop on Philosophy \& Engineering. WPE. 2008. Available from: https://www.academia.edu/174751/Toward_an_Epistemology_of_Engineering Accessed 9/1/17

29. Biggs, J. \& Tang, C. (2007), Teaching for Quality Learning at University. Maidenhead. SRHE. $3^{\text {rd }}$ Edition. 
30. PAPER AUTHORS - ANONYMISED 